\title{
PENGEMBANGAN BAHAN AJAR BERBASIS INTEGRASI INTERKONEKSI UNTUK MEMFASILITASI PENINGKATAN KEMAMPUAN BERPIKIR KRITIS MAHASISWA
}

\author{
Suparni \\ UIN Sunan Kalijaga Yogyakarta \\ suparni71@yahoo.com
}

\begin{abstract}
Abstrak
Pada saat ini pembelajaran yang mengutamakan kemampuan berpikir kritis mahasiswa banyak menjadi pembicaraan. Berpikir kritis merupakan salah satu karakter yang akhir-akhir ini memang menjadi isu pendidikan, selain menjadi bagian dari proses pembentukan akhlak anak bangsa.. Untuk mengembangkan kemampuan berpikir kritis mahasiswa perlu dilakukan inovasi pembelajaran. Berdasarkan pemikiran itulah maka peneliti akan melakukan penelitian pengembangan untuk mengembangkan bahan ajar yang berbasis integrasi interkoneksi untuk memfasilitasi peningkatan kemampuan berpikir kritis mahasiswa program Studi Pendidikan Matematika Fakultas Sains dan Teknologi.Penelitian ini merupakan penelitian pemgembangan dengan menggunakan desain yang mengadaptasi dari langkah-langkah penelitian dan pengembangan (Research and Development) yang dikembangkan oleh Borg dan Gall. Langkah tersebut terdiri dari tiga tahap, yaitu tahap pendahuluan, tahap pengembangan, dan tahap uji produk. Hasil penelitian ini menunjukkan bahwa telah berhasil dikembangkan bahan ajar berbasis integrasi interkoneksi dengan kualitas sangat baik dengan persentase keidealan sebesar 87,6 \% dari ahli materi, 86\% ahli media, dan mampu meningkatkan kemampuan berpikir kritis mahasiswa sebesar 17,5135.
\end{abstract}

Kata Kunci: Bahan ajar, integrasi interkoneksi, berpikir kritis.

\section{PENDAHULUAN}

Fakultas Sains dan Teknologi

Universitas Islam Negeri Sunan

Kalijaga dengan sepuluh program studi

(Matematika, Fisika, Kimia, Biologi,

Pendidikan Matematika, Pendidikan

Fisika, Pendidikan Kimia dan

Pendidikan Biologi, Teknik Industri,

dan Teknik Informatika) merupakan

salah satu fakultas baru yang ada di

UIN Sunan Kalijaga. Visi, misi, dan tujuan fakultas di antaranya adalah mengembangkan pendidikan dan pengajaran dalam bidang Sains dan

Teknologi yang integratif dan interkonektif yang berkepribadian ZIKR (Zero-based, Iman, Konsisten, dan Result-oriented) dan mengembangkan penelitian yang berkualitas dalam bidang Sains dan Teknologi, maka setiap kegiatan pendidikan dan pengajaran di Fakultas Sains dan Teknologi selalu diusahakan untuk dapat mengembangkan karakter dan kepribadian mahasiswa.

Pada saat ini pembelajaran yang mengutamakan kemampuan berpikir kritis mahasiswa banyak menjadi pembicaraan. Tuntutan ini muncul seiring dengan perubahan kebutuhan 
Pengembangan Bahan Ajar Berbasis Integrasi Interkoneksi untuk Memfasilitasi

Peningkatan Kemampuan Berpikir Kritis Mahasiswa

Suparni

akan kemampuan para pekerja di era

informatika ini. Para pekerja yang

memasuki tempat kerja di masa

mendatang harus benar-benar memiliki

berbagai kemampuan yang menjadikan

mereka pemikir sistem, pemecah

masalah, pembuat keputusan secara

mandiri, dan yang tak pernah henti

belajar sepanjang hidup mereka.

Penting bagi mahasiswa untuk menjadi

seorang pemikir kritis sejalan dengan

meningkatnya jenis pekerjaan di masa yang akan datang.

Berpikir kritis merupakan salah

satu karakter yang akhir-akhir ini memang menjadi isu pendidikan, selain menjadi bagian dari proses pembentukan akhlak anak bangsa.

Kemampuan berpikir kritis juga diperjelas melalui UU No 20 tahun 2003 tentang Sistem Pendidikan Nasional, yang berbunyi “ Pendidikan nasional berfungsi mengembangkan kemampuan dan membentuk watak serta peradaban bangsa yang bermartabat dalam rangka mencerdaskan kehidupan bangsa, bertujuan untuk berkembangnya potensi peserta didik agar menjadi manusia yang beriman dan bertakwa kepada Tuhan Yang Maha Esa, berakhlak mulia, sehat, berilmu, cakap, kreatif, mandiri, dan menjadi warga negara yang demokrasi serta bertanggung jawab."

Salah satu potensi yang harus dikembangkan dan dibentuk di perguruan tinggi adalah berpikir kritis. Berpikir kritis merupakan proses mental yang terorganisasikan dan berperan dalam proses mengambil keputusan untuk menyelesaikan masalah. Berpikir kritis mencakup kegiatan menganalisis dan menginterpretasikan data dalam kegiatan penemuan ilmiah. Kompetensi berpikir kritis, membuat keputusan, memecahkan masalah, dan bernalar sangat dibutuhkan dalam berprestasi di dunia kerja. Oleh karena itu, mahasiswa Program Studi Pendidikan Matematika Fakultas Sains dan Teknologi UIN Sunan Kalijaga sebagai calon pendidik selain harus memiliki empat kompetensi utama sebagai pendidik (kompetensi pedagogi, profesional, kepribadian, dan sosial) juga diharapkan memiliki bekal ketrampilan berpikir kritis, menyelesaikan masalah, mengambil keputusan, dan berpikir kreatif.

Untuk mengembangkan kemampuan berpikir kritis mahasiswa perlu dilakukan inovasi pembelajaran. Facione (2009: 145) menyebutkan bahwa dengan pembelajaran yang inovatif diharapkan mahasiswa menjadi 
Jurnal Derivat Volume 2 No. 2 Desember 2015 (ISSN: 2407 - 3792)

Halaman 1-19

pribadi pemikir kritis yang dapat dilihat dari ketrampilannya menginterpretasi, menganalisis, mengevaluasi, dan menyimpulkan, menjelaskan apa yang dipikirkannya dan membuat keputusan, menerapkan kekuatan berpikir kritis pada dirinya sendiri, dan meningkatkan kemampuan berpikir kritis terhadap pendapat-pendapat yang dibuatnya. Seseorang yang mampu melakukan keenam ketrampilan kognitif tersebut berarti kemampuan berpikir ktitisnya jauh di atas seseorang yang hanya mampu melakukan interpretasi, analisis, dan evaluasi saja. Dengan demikian dapat dibuat penjenjangan kemampuan berpikir kritis seseorang. Tingkat kemampuan berpikir kritis setiap orang berbeda-beda dan perbedaan ini dapat dipandang sebagai suatu keberlanjutan yang dimulai dari tingkatan terendah sampai tertinggi.

\begin{tabular}{llr}
\multicolumn{1}{c}{ Peneliti } & \multicolumn{1}{c}{ telah } & melakukan \\
penelitian & berkaitan & dengan \\
penjenjangan kemampuan & berpikir \\
kritis mahasiswa Program Studi & Satika pada tahun
\end{tabular}
2011. Hasil penelitian ini menunjukkan bahwa tingkat kemampuan berpikir kritis mahasiswa Program Studi Pendidikan Matematika Fakultas Sains dan Teknologi UIN Sunan Kalijaga dalam menyelesaikan masalah hanya sampai tingkat kemampuan berpikir kritis 3 (kritis). Penjenjangan

kemampuan berpikir kritis mahasiswa Program Studi Pendidikan Matematika Fakultas Sains dan Teknologi UIN Sunan Kalijaga dalam menyelesaikan masalah terdiri dari TKBK 3 (kritis) sebanyak 17,4 \%, TKBK 2 (cukup kritis) sebanyak 56,5\%, dan TKBK 1 (kurang kritis) sebanyak 26,1\%.

Berdasarkan hasil penelitian tersebut, maka peneliti berusaha untuk mengembangkan kemampuan berpikir kritis mahasiswa dengan melakukan penelitian tindakan kelas dengan menggunakan pendekatan integrasi interkoneksi. Hasil penelitian ini adalah pembelajaran matematika dengan pendekatan integrasi interkoneksi dapat mengembangkan kemampuan berpikir kritis mahasiswa Program Studi Pendidikan Matematika Fakultas Sains dan Teknologi. Hal ini dapat dilihat dari analisis data skor TKBK pada saat pra tindakan sebesar 23 pada siklus I sebesar 27,7, dan pada siklus II sebesar 36,6. Berdasarkan rekomendasi dari hasil penelitian ini, maka peneliti ingin melanjutkannya dengan melakukan penelitian eksperimen.

$$
\text { Berdasarkan hasil penelitian }
$$
tersebut, maka peneliti melanjutkan lagi dengan penelitian eksperimen untuk menganalisis peningkatan kemampuan berpikir kritis mahasiswa 
Pengembangan Bahan Ajar Berbasis Integrasi Interkoneksi untuk Memfasilitasi

Peningkatan Kemampuan Berpikir Kritis Mahasiswa

Suparni

yang mendapat perlakuan pembelajaran

matematika dengan pendekatan

integrasi interkoneksi dibandingkan

dengan kelas kontrol yang

menggunakan pembelajaran

konvensional. Hasil penelitian ini

adalah bahwa peningkatan kemampuan

berpikir kritis mahasiswa yang

menggunakan pembelajaran

matematika dengan integrasi

interkoneksi lebih tinggi secara

signifikan dibandingkan dengan

mahasiswa yang belajar dengan

pembelajaran konvensional.

Berdasarkan pemikiran itulah
maka peneliti tertarik untuk
melanjutkan penelitian dengan

melakukan penelitian pengembangan

untuk mengembangkan bahan ajar yang

berbasis integrasi interkoneksi untuk

memfasilitasi peningkatan kemampuan

berpikir kritis mahasiswa program

Studi Pendidikan Matematika Fakultas

Sains dan Teknologi.

Penelitian ini bertujuan untuk:

a. Menghasilkan bahan ajar berbasis integrasi interkoneksi yanng dapat memfasilitasi peningkatan kemampuan berpikir kritis mahasiswa Program Studi

Pendidikan Matematika Fakultas

Sains dan Teknologi UIN Sunan

Kalijaga Yogyakarta b. Mengetahui kualitas bahan ajar yang layak digunakan.

Penelitian sebelumnya yang sudah dilakukan oleh peneliti yang berkaitan dengan penelitian ini adalah sebagai berikut.

Penelitian yang dilakukan oleh Suparni, S.Pd., M.Pd. dengan judul "Penjenjangan Kemampuan Berpikir Kritis Dalam Rangka Pengembangan Karakter Mahasiswa Program Studi Pendidikan Matematika Fakultas Sains dan Teknologi UIN Sunan Kalijaga”. Penelitian ini merupakan penelitian deskriptif kualitatif. Hasil penelitian ini menunjukkan bahwa tingkat kemampuan berpikir kritis mahasiswa Program Studi Pendidikan Matematika Fakultas Sains dan Teknologi UIN Sunan Kalijaga dalam menyelesaikan masalah hanya sampai tingkat kemampuan berpikir kritis 3 (kritis). Penjenjangan kemampuan berpikir kritis mahasiswa Program Studi Pendidikan Matematika Fakultas Sains dan Teknologi UIN Sunan Kalijaga dalam menyelesaikan masalah terdiri dari TKBK 3 (kritis) sebanyak 17,4 \%, TKBK 2 (cukup kritis) sebanyak 56,5 $\%$, dan TKBK 1 (kurang kritis) sebanyak $26,1 \%$.

Penelitian ini merupakan kelanjutan dari penelitian yang dilakukan sebelumnya oleh peneliti 
Jurnal Derivat Volume 2 No. 2 Desember 2015 (ISSN: 2407 - 3792)

Halaman 1-19

dengan judul "Pengembangan

Kemampuan Berpikir Kritis Mahasiswa

Program Studi Pendidikan Matematika

Melalui Pendekatan Integrasi

Interkoneksi" yang dilaksanakan pada

tahun 2013. Penelitian ini merupakan

penelitian tindakan kelas yang

dilaksanakan 2 siklus. Hasil penelitian

ini adalah pembelajaran matematika

dengan pendekatan integrasi

interkoneksi dapat mengembangkan

kemampuan berpikir kritis mahasiswa

Program Studi Pendidikan Matematika

Fakultas Sains dan Teknologi UIN

Sunan Kalijaga. Hal ini dapat dilihat

dari analisis data skor TKBK pada saat

pra tindakan sebesar 23 pada siklus I

sebesar 27,7, dan pada siklus II sebesar

36,6. Berdasarkan rekomendasi dari

hasil penelitian ini, maka peneliti ingin

melanjutkannya dengan melakukan

penelitian eksperimen.

Sebagai kelanjutan dari

penelitian tersebut, peneliti melakukan

penelitian eksperimen untuk menelaah

peningkatan kemampuan berpikir kritis

mahasiswa yang mengikuti

pembelajaran matematika dengan

pendekatan integrasi interkoneksi

dibandingkan dengan kemampuan

berpikir kritis mahasiswa yang

mengikuti pembelajaran konvensional.

Hasil dari penelitian ini adalah bahwa

peningkatan kemampuan berpikir kritis mahasiswa yang menggunakan

pembelajaran matematika dengan

pendekatan integrasi interkoneksi

sebesar 8,136363636 lebih tinggi

secara signifikan dibandingkan dengan

kemampuan berpikir kritis mahasiswa

yang menggunakan pembelajaran

konvensional sebesar 5,071428571.

Berdasarkan hasil penelitian tersebut, maka peneliti berminat untuk melanjutkannya dengan melakukan penelitian pengembangan untuk mengembangkan bahan ajar matematika untuk memfasilitasi peningkatan kemampuan berpikir kritis mahasiswa.

\section{KAJIAN TEORI}

\section{a. Pendekatan Integrasi \\ Interkoneksi}

Pada Kerangka Dasar Keilmuan dan Pengembangan Kurikulum UIN Sunan Kalijaga (2006: 15) disebutkan bahwa UIN Sunan Kalijaga dituntut untuk mengembangkan pendidikan yang berperspektif Qur'ani, yaitu pendidikan yang utuh yang menyentuh seluruh domain yang disebut Alloh dalam kitab suci (hadlarah al-nash), juga mendalam dalam kajian-kajian keilmuannya (hadlarah al-'ilm), serta peduli dengan wilayah 'amali, praktis nyata dalam realitas dan etika (hadlarah al-falsafah). Islam 
Pengembangan Bahan Ajar Berbasis Integrasi Interkoneksi untuk Memfasilitasi

Peningkatan Kemampuan Berpikir Kritis Mahasiswa

Suparni

mengembangkan ilmu-ilmu

qauliyah/hadlarah al-nash (ilmu-ilmu

yang berkaiyan dengan teks

keagamaan), ilmu-ilmu

kauniyyah/hadlarah al'ilm (ilmu-ilmu

kealaman dan kemasyarakatan), dan

ilmu-ilmu hadlarah al-falsafah (ilmu-

ilmu etis filosofis). Keilmuan yang

dikembangkan di UIN Sunan Kalijaga

bersifat integratif dan interkonektif

dalam wilayah internal ilmu-ilmu

keislaman, dan ilmu-ilmu umum.

Pendekatan integratif adalah terpadunya kebenaran wahyu (burhan ilahi) dalam bentuk pembidangan mata kuliah yang terkait dengan nash (hadlarah al-nash), dengan bukti-bukti yang ditemukan di alam semesta ini (burhan kaum) dalam bentuk pembidangan matakuliah empiriskemasyarakatan dan kealaman (hadlarah al-ilm), dan pembidangan matakuliah yang terkait dengan falsafah dan etika (hadlarah al-falsafah). Pendekatan interkonektif adalah terkaitnya satu pengetahuan dengan pengetahuan yang lain melalui satu hubungan yang saling menghargai dan mempertimbangkan.

Pendekatan integrasi-

interkoneksi dalam pembidangan matakuliah yang mencakup tiga dimensi pengembangan ilmu, yakni hadlarah al-nas, hadlarah al'ilm, dan hadlarah al-fasafah adalah upaya mempertemukan kembali antara ilmuilmu keislaman (islamic scinces) dengan ilmu-ilmu umum (modern scinces) sehingga tercapailah kesatuan ilmu yang integratif dan interkonektif. Implementasi Integrasi interkoneksi dapat diterapkan dalam berbagai level, yaitu:

a. level filosofi

Integrasi dan interkoneksi pada level filosofi dalam pengajaran dimaksudkan bahwa setiap mata kuliah harus diberi nilai fundamental eksistensial dalam kaitannya dengan disiplin keilmuan lainnya dan dalam hubungannya dengan nilai-nilai humanistiknya.

b. level materi

Integrasi dan interkoneksi pada level materi merupakan suatu proses bagaimana mengintegrasikan nilainilai kebenaran universal umumnya dan keislaman khususnya ke dalam pengajaran mata kuliah umum, dan sebaliknya ilmu-ilmu umum ke dalam kajian-kajian keagamaan dan keislaman.

c. level metodologi

Integrasi dan interkoneksi pada level metodologi adalah metodologi dalam pengembangan ilmu yang bersangkutan. Ketika sebuah disiplin ilmu diintegrasikan atau 


$$
\begin{aligned}
& \text { diinterkoneksikan dengan disiplin } \\
& \text { ilmu lain, maka secara metodologis } \\
& \text { ilmu interkonektif tersebut harus } \\
& \text { menggunakan pendekatan dan } \\
& \text { metode yang aman bagi ilmu } \\
& \text { tersebut. }
\end{aligned}
$$

d. level strategi

Integrasi dan interkoneksi pada
level strategiadalah level pelaksanaan atau praksis dari proses pembelajaran keilmuan integratif interkonektif, sehingga kualitas keilmuan serta ketrampilan mengajar dosen menjadi kunci keberhasilan perkuliahan berbasis paradigma interkonektif. Pembelajaran dengan model active learning dengan berbagai strategi dan metodenya meenjadi keharusan.

Dalam penelitian ini, pendekatan integrasi interkoneksi akan diterapkan dalam level materi dan strategi. Pendekatan integrasi interkoneksi akan diterapkan dengan mengaitkan materi perkuliahan dengan materi perkuliahan yang lain, keislaman, dan kehidupan sehari-hari dengan menggunakan metode pembelajaran kooperatif tipe Jigsaw.

\section{b. Kemampuan Berpikir Kritis}

$$
\begin{aligned}
& \text { Berpikir kritis digunakan } \\
& \text { untuk menjelaskan berpikir yang } \\
& \text { dengan maksud jelas dan terarah pada } \\
& \text { tujuan. Diane Halpern (1984: } 3)
\end{aligned}
$$

menyebutkan "The term critical thinking is used to describe thinking that is purposeful and goal directed". Berpikir kritis adalah aktivitas mental dari peninjauan kembali, penilaian, dalam usaha untuk membuat keputusan, mengartikan sesuatu secara rasional (Debra Mc Gregor. 2007: 209). Selain itu, Oon Seng Tan (2004: 43) menyebutkan bahwa berpikir kritis dapat didefinisikan sebagai berikut.

Critical thinking is defined as an awareness of one's own thinking (self reflection) and the ability (foundation skill) and willingness (willingness to question) to clarify and improve understanding which aids in drawing appropiate conclusions and making the best decisions possible within a context (knowledge base)

Menurut Elder dan Paul (2008) dalam www.criticalthinking.org (online) terdapat 6 tingkatan kemampuan berpikir kritis sebagai berikut.

a. Berpikir yang tidak direfleksikan (unreflective thinking)

Pemilik tidak menyadari peran berpikir dalam kehidupan, kurang mampu menilai pemikirannya, dan mengembangkan beragam kemampuan berpikir tanpa menyadarinya. Akibatnya gagal 
Pengembangan Bahan Ajar Berbasis Integrasi Interkoneksi untuk Memfasilitasi Peningkatan Kemampuan Berpikir Kritis Mahasiswa

Suparni

menghargai berpikir sebagai

aktivitas yang melibatkan elemen

bernalar. Mereka tidak menyadari

standar yang tepat untuk penilaian

berpikir yaitu kejelasan, ketepatan,

ketelitian, relevansi, dan kelogisan.

b. Berpikir yang menantang

(challenged thinking)

Pemikir sadar peran berpikir dalam

kehidupan, menyadari berpikir

berkualitas membutuhkan berpikir

reflektif yang disengaja, dan menyadari berpikir yang dilakukan sering kekurangan tetapi tidak dapat mengi-dentifikasi di mana kekurangannya.

c. Berpikir permulaan (beginning thinking)

Pemikir mulai memodifikasi beberapa kemampuan berpikirnya, tetapi memiliki wawasan terbatas. Mereka kurang memiliki perencanaan yang sistematis untuk meningkatkan kemampuan berpikirnya.

d. Berpikir latihan (practicing thinking) Pemikir menganalisis pemikirannya secara aktif dalam sejumlah bidang namun mereka masih mempunyai wawasan terbatas dalam tingkatan berpikirnya yang mendalam.

e. Berpikir lanjut (advanced thinking)

Pemikir aktif menganalisis pikirannya, memiliki pengetahuan yang penting tentang masalah pada tingkat berpikir yang mendalam. Namun mereka belum mampu berpikir pada tingkat yang lebih tinggi secara konsisten pada semua dimensi klehidupannya.

f. Berpikir yang unggul (master thinking)

Pemikir menginnternalisasi kemampuan dasar berpikir secara mendalam, berpikir kritis dilakukan secara sadar dan menggunakan intuisi yang tinggi. Mereka menilai pikiran tentang kejelasan, ketepatan, ketelitian, relevansi, dan kelogisan secara intuitif.

Penjenjangan kemampuan berpikir kritis ini dibandingkan dengan tingkat Kemampuan Berpikir Kritis Elder dan Paul (2008) disajikan dalam tabel berikut.

Tabel 1. Perbandingan Penjenjangan Kemampuan Berpikir Kritis dengan Tingkat Kemampuan Berpikir Kritis Elder dan Paul

\begin{tabular}{|l|l|}
\hline \multicolumn{1}{|c|}{$\begin{array}{c}\text { TKBK Elder dan } \\
\text { Paul }\end{array}$} \\
\hline $\begin{array}{l}\text { Berpikir yang tidak } \\
\text { direfleksikan }\end{array}$ \\
\hline $\begin{array}{l}\text { Berpikir yang } \\
\text { Menantang }\end{array}$ \\
\hline Berpikir Permulaan \\
\hline Berpikir latihan \\
\hline Berpikir lanjut \\
\hline Berpikir yang unggul \\
\hline
\end{tabular}


TKBK 0 (tidak kritis) dapat disetarakan dengan berpikir yang tidak direfleksikan pada TKBK Elder dan Paul. Hal ini dikarenakan mahasiswa dalam berpikir masih belum melibatkan elemen bernalar dan standar intelektual bernalar (standar penilaian). Mahasiswa juga mengembangkan beragam kemampuan berpikir seperti mengenali hubungan-hubungan, mengenali informasi, dan mengidentifikasi masalah. Namun kemampuan ini belum diterapkan dengan jelas dalam bentuk penalaran yang logis dan sistematis ketika menyelesaiakan masalah matematika.

TKBK 1 dapat disetarakan dengan berpikir yang menantang karena mahasiswa pada tingkat ini telah mengembangkan kemampuan berpikir. Namun kemampuan berpikirnya masih terbatas yaitu menggali informasi yang memenuhi standar intelektual bernalar, menggali dan mengembangkan kesadaran akan konsep dan ide yang memenui standar jelas. Mahasiswa menyadari adanya kelemahan pada berpikirnya namun tidak mengetahui di mana kelemahannya sehingga mahasiswa menerapkan konsep-konsep secara tidak tepat, sudut pandang penyelesaian masalah tidak jelas, penalarannya juga tidak jelas dan tidak logis.

TKBK 2 dapat disetarakan dengan berpikir permulaan karena mahasiswa pada tingkat ini mulai memodifikasi kemampuan berpikirnya di antaranya mengidentifikasi masalah, mengenali hubungan-hubungan, mencari konsep-konsep yang relevan dan tepat, menggunakan analogi dalam menyelesaikan masalah namun wawasannya terbatas. Hal ini ditunjukkan dengan penalaran yang dilakukan masih belum memenuhi standar jelas dan logis, serta sudut pandang tidak jelas dan tidak luas (ditandai adanya penggunaan analogi yang tidak dikembangkan sesuai situasi yang diberikan pada masalah yang diselesaikan).

TKBK 3 memuat berpikir latihan karena mahasiswa yang berada pada tingkat ini aktif menganalisis berpikirnya. Mereka berpikir analitis terhadap elemen bernalar dan standar intelektual bernalar serta menerapkan pikiran analitisnya dalam menyelesaikan masalah matematika. Mahasiswa juga mengetahui apa yang akan dilakukan dengan standar intelektual 
sebagai standar penilaian sehingga

elemen informasi dan penyimpulan dipenuhi semua standarnya, elemen konsep dan ide serta elemen sudut pandang sebagian besar standarnya juga dipenuhi.

\section{c. Hakikat Matematika}

Ibrahim dan Suparni menyebutkan bahwa Belajar matematika dimanfaatkan untuk mengakui kebesaran Alloh, mengakui bahwa hanya Alloh yang maha besar, kita kecil meskipun dengan gelar doktor, master, maupun profesor sekalipun. Al Qur'an surat Ali Imraan ayat 199 menyebutkan



199. .... Sesungguhnya Allah amat cepat perhitungan-Nya.

Maksudnya dari berbagai pakar matematika maupun secanggih apapun alat yang diciptakan manusia tidak ada yang mampu mengungguli kecepatannya dalam menghitung Bahkan pada tingkat kecermatan dan ketelitian, Allah Maha teliti, (sebesar biji dzarrah amal manusia baik maupun buruk akan dibalasnya). Firman Allah dalam QS Al Zalzalah (99) ayat 7-8 yang berbunyi:

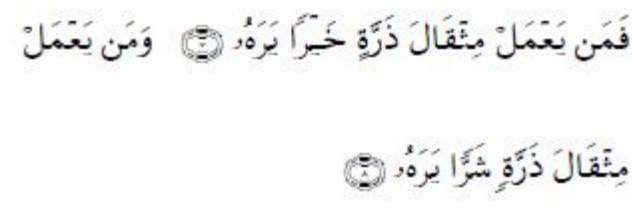

7. Barangsiapa yang mengerjakan kebaikan seberat dzarrahpun, niscaya Dia akan melihat (balasan)nya.

8. dan Barangsiapa yang mengerjakan kejahatan sebesar dzarrahpun, niscaya Dia akan melihat (balasan)nya pula.

$$
\text { Barangsiapa yang melakukan }
$$
suatu amal baik/buruk sebesar biji dzarroh, Allah akan mengetahuinya. Kecermatan Allah dalam waktu, sampai pada satuan detik, "Ketika dating ajal seseorang, maka tidak akan DIPERLAMBAT SEDETIKPUN, dan tidak akan DIPERCEPAT SEDETIKPUN. Ketepatan waktunya perdetik, padahal berapa banyak orang yang sampai pada ajalnya dalam setiap hari dari seluruh manusia yang ada di ? Sementara kita manusia cenderung untuk mengabaikan waktu, tidak disiplin, menggunakan waktu untuk hal-hal yang tidak produktif, maksiat pada Allah. Na'udzubillaahimindzalik. Walau dalam matematika ada GALAT, LIMIT, NUMERIK, tapi tetap saja tidak akan menandingi Allah dalam hal ketelitian, kecermatan. ALLAH MAHA BESAR, kita manusia kecil, tidak boleh sombong, harus tunduk pada Allah. 
Pengertian matematika sangat sulit didefinisikan secara akurat. Pada umumnya orang awam hanya akrab dengan satu cabang matematika elementer yang disebut aritmetika atau ilmu hitung. Aritmetika ini secara informal dapat didefinisikan sebagai ilmu tentang berbagai bilangan yang bisa langsung diperoleh dari bilangan-bilangan bulat 0 , $1,-1,2,-2, \ldots$, dan seterusnya, melalui beberapa operasi dasar: tambah, kurang, kali dan bagi. Apabila mendiskusikan atau membicarakan mengenai "apa matematika itu sebenarnya", dengan kata lain mendiskusikan tentang hakekat matematika. Matematika memiliki pengertian yang bermacam-macam bergantung pada cara orang memandangnya. Bagi seorang pengajar matematika, perbedaan dalam cara pandang tentang matematika ini, akan memberikan implikasi pada perbedaan dalam memilih strategi pembelajaran matematika di kelas. Namun, idealnya seorang pengajar matematika mengetahui beragam pandangan tentang hakekat matematika, karena akan membantunya dalam memilih strategi pembelajaran matematika di kelas dengan tepat.

Pada bagian ini akan dikupas beberapa pandangan para ahli terhadap hakekat matematika.

1. Matematika sebagai Ilmu Deduktif
2. Matematika sebagai Ilmu tentang Pola dan Hubungan

3. Matematika sebagai Bahasa

4. Matematika sebagai Ilmu tentang Struktur yang Terorganisasikan

5. Matematika sebagai Seni

6. Matematika sebagai Aktivitas Manusia

\section{METODE PENELITIAN}

Subyek dalam penelitian ini adalah pihak-pihak yang terlibat selama proses pengujian produk, yakni validator/penilai/ahli instrumen tes KBK dan bahan ajar berbasis integrasi interkoneksi, enam mahasiswa uji coba keterbacaan tes KBK, 10 mahasiswa uji coba terbatas tes KBK, lima mahasiswa uji coba keterbacaan bahan ajar, dosen, dan mahasiswa uji coba produk bahan ajar yang dikembangkan. Sampel uji coba produk yaitu mahasiswa Program Studi Pendidikan Matematika yang mengambil mata Kuliah Strategi Pembelajaran Matematika semester gasal tahun akademik 2014/2015 sebanyak 41 mahasiswa.

Jenis penelitian ini adalah penelitian pengembangan untuk menghasilkan produk berupa bahan ajar berbasis integrasi interkoneksi. Penelitian pengembangan bahan ajar ini menggunakan desain yang 
Pengembangan Bahan Ajar Berbasis Integrasi Interkoneksi untuk Memfasilitasi

Peningkatan Kemampuan Berpikir Kritis Mahasiswa

Suparni

mengadaptasi dari langkah-langkah

penelitian dan pengembangan

(Research and Development) yang dikembangkan oleh Borg dan Gall.

Langkah tersebut terdiri dari tiga tahap, yaitu tahap pendahuluan, tahap pengembangan, dan tahap uji produk (Sugiyono:2008).

Instrumen penelitian adalah alat atau fasilitas yang digunakan oleh peneliti dalam mengumpulkan data agar pekerjaan lebih mudah dan hasilnya lebih baik, dalam arti lebih cermat, lengkap, dan sistematis, sehingga lebih mudah diolah (Arikunto, 2006). Instrumen-instrumen yang dikembangkan adalah instrumen yang dibutuhkan sesuai dengan pengembangan bahan ajar. Instrumeninstrumen ini digunakan untuk mengumpulkan beberapa data, yaitu: kemampuan berpikir kritis mahasiswa setelah proses pembelajaran, proses pembelajaran saat menggunakan bahan ajar berbasis integrasi interkoneksi, pendapat dosen dan mahasiswa selama pembelajaran, kualitas bahan ajar menurut para ahli, dan dokumentasi pada saat penelitian.

Data yang telah dikumpulkan dengan menggunakan instrumen, selanjutnya akan dianalisis dan diarahkan untuk menjawab pertanyaan penelitian.
1. Analisis Soal Kemampuan Berpikir Kritis (KBK) berupa validitas soal tes KBK, daya beda, tingkat kesukaran, reliabilitas.

2. Analisis Data Kevalidan Bahan Ajar Penentuan kualitas bahan ajar berbasis integrasi interkoneksi didasarkan pada penilaian validator yaitu dua orang dosen ahli pendidikan. Berdasarkan tehnik analisis data yang digunakan, data penilaian dari validator yang berupa data kualitatif diubah menjadi bentuk kuantitatif. Data kuantitatif yang dihasilkan kemudian ditabulasi dan dianalisis tiap komponen penilaian. Komponen penilain bahan ajar terdiri dari komponen kelayakan isi, komponen kebahasaan, dan komponen tampilan.

3. Penilaian komponen kelayakan isi terdiri dari cakupan materi, akurasi materi, kekontekstualan, memfasilitasi kemampuan berpikir kritis. Penilaian komponen kebahasaan terdiri dari kesesuaian dengan tingkat perkembangan mahasiswa, komunikatif, dialogis dan interaktif, lugas, koherensi dan keruntutan alur berfikir, kesesuaian dengan kaidah bahasa Indonesia yang benar, dan penggunaan istilah maupun 
simbol. Sedangkan penilaian komponen penyajian terdiri dari tehnik penyajian, penyajian pembelajaran, dan pendukung penyajian. Skor terakhir yang diperoleh dikonversi menjadi tingkat kelayakan produk secara kualitatif dengan menggunakan kriteria penilaian ideal dan persentase keidealan. Nilai ratarata yang diperoleh pada tiap komponen dikonversikan ke dalam tabel kategori penilaian ideal, begitu juga untuk persentase keidealan dikonversikan dalam tabel persentase ketegori penilaian ideal.

Teknik analisis data pada penelitian ini yaitu

a. Uji Prasyarat Analisis Data,

Uji prasyarat analisis data penelitian diperlukan untuk mengetahui apakah data yang dikumpulkan memenuhi syarat untuk dianalisis lebih lanjut atau tidak. Uji prasyarat analisis data meliputi uji normalitas, uji homogenitas variansi, dan uji perbedaan rata-rata.

b. Uji Analisis Data, Setelah melakukan pengumpulan data secara lengkap, selanjutnya peneliti menganalisis data tersebut untuk memperoleh jawaban atas rumusan masalah yang telah ditetapkan. Analisis data bertujuan agar data tersebut mempunyai arti dan dapat ditarik kesimpulan. Data yang diperoleh dalam penelitian ini, pertama-tama dilakukan analisis statistik deskriptif, dengan menghitung rata-rata, varians, dan simpangan baku dari masingmasing kelompok data, disertai beberapa tabel sehingga diperoleh suatu gambaran umum. Data yang dianalisis dalam penelitian ini adalah nilai $\mathrm{N}$-Gain dari nilai postes dan pretes.

\section{HASIL DAN PEMBAHASAN}

\section{a. Pengembangan Bahan Ajar}

\section{Berbasis Integrasi Interkoneksi}

Produk akhir dari penelitian pengembangan ini berupa bahan ajar berbasis integrasi interkoneksi untuk memfasilitasi peningkatan kemampuan berpikir kritis mahasiswa. Produk bahan ajar ini hanya difokuskan pada materi Hakikat Matematika yang merupakan salah satu materi pada perkuliahan Strategi Pembelajaran Matematika yang diajarkan pada mahasiswa Program Studi Pendidikan Matematika semester gasal tahun akademik 2015/2016. 


\begin{abstract}
Bahan ajar ini tidak hanya mengajak mahasiswa mempelajari hakikat matematika saja, namun setiap materi hakikat matematika di dalamnya diintegrasikan dengan materi keislaman dan diinterkoneksikan dengan materi bidang yang lain sesuai dengan materi hakikat matematikanya.
\end{abstract}

Metode penelitian yang digunakan dalam penelitian ini adalah metode penelitian dan pengembangan (Research and Development, $R \& D$ ) yang mengadaptasi langkah-langkah penelitian dan pengembangan yang dikembangkan oleh Borg dan Gall. Metode penelitian dan pengembangan ini meliputi 3 tahapan, yaitu pendahuluan, pengembangan dan uji coba produk. Berikut penjelasan tahapan-tahapan dalam penelitian dan pengembangan bahan ajar berbasis integrasi interkoneksi yang dikembangkan.

\section{Pendahuluan}

Tahap ini merupakan tahap awal dari metode penelitian dan pengembangan yang dikembangkan oleh Borg dan Gall.

a.Studi pendahuluan yang meliputi :

1)Wawancara dan observasi terhadap mahasiswa untuk mengetahui permasalahan yang terjadi berkenaan dengan pembelajaran matematika khususnya pada mata kuliah

Strategi Pembelajaran

Matematika. Pengamatan

peneliti terhadap perkuliahan

pada tahun-tahun sebelumnya

disimpulkan bahwa

kemampuan berpikir kritis

mahasiswa masih rendah.

2)Analisis kurikulum mengenai tujuan pembelajaran matematika pada mata kuliah Strategi Pembelajaran Matematika. Berdasarkan analisis terhadap materi perkuliahan Strategi Pembelajaran Matematika, maka dipilihlah materi Hakikat Matematika untuk dapat dikembangkan bahan ajar.

Materi yang digunakan adalah Hakikat matematika, yaitu matematika sebagai: ilmu deduktif, ilmu tentang pola dan hubungan, bahasa, ilmu tentang struktur yangn terorganisasikan, seni, dan aktivitas manusia.

Studi pendahuluan penggunaan bahan ajar sebagai media pembelajaran. Dari hasil studi pendahuluan ini peneliti mengetahui bahwa penggunaan bahan ajar sebagai media belajar khususnya dalam 
Jurnal Derivat Volume 2 No. 2 Desember 2015 (ISSN: 2407 - 3792)

Halaman 1-19

\begin{abstract}
pembelajaran matematika sebenarnya sudah sering dilakukan. Namun di pada mata kuliah Strategi Pembelajaran Matematika, penggunaan bahan ajar sebagai media pembelajaran matematika untuk memfasilitasi peningkatan kemampuan berpikir kritis belum pernah dilakukan. Ketika peneliti menanyakan pendapat mahasiswa terkait bagaimana jika konsep atau materi hakikat matematika dikemas dalam bentuk bahan ajar, ternyata mereka memberikan respon sangat antusias dan tertarik dengan materi atau konsep matematika yang dikemas dalam bentuk bahan ajar tersebut.
\end{abstract}

b Melakukan studi pustaka untuk menentukan solusi yang sekiranya tepat untuk memenuhi kebutuhan pembelajaran yang telah ditemukan pada tahap sebelumnya. Salah satu solusi yang kemudian ditawarkan dan dikembangkan adalah bahan ajar matematika berbasis integrasi interkoneksi. Sementara materi yang disajikan adalah materi Hakikat Matematika. Maka akhir dari solusi yang dikembangkan adalah pengembangan bahan ajar berbasis integrasi interkoneksi untuk memfasilitasi peningkatan kemampuan berpikir kritis mahasiswa.

Berdasarkan hasil pada tahap pendahuluan ini, didapat kesimpulan bahwa kondisi mahasiswa yang akan diujicobakan menggunakan bahan ajar berbasis integrasi interkoneksi kemampuan berpikir kritisnya masih rendah. Media pembelajaran yang digunakan masih belum mencukupi kebutuhan pembelajaran. Oleh karena itu, perlu adanya media pembelajaran yang diharapkan mampu menjawab permasalahan di atas. Salah satunya adalah bahan ajar berbasis integrasi interkoneksi.

\section{Pengembangan}

Analisis terhadap tahap sebelumnya melatarbelakangi peneliti untuk melakukan tahap pengembangan yakni sebagai berikut:

1) Pembuatan bahan ajar yang fokus membahas materi hakikat matematika pada perkuliahan Strategi pembelajaran Matematika untuk mahasiswa semester 3 
Pengembangan Bahan Ajar Berbasis Integrasi Interkoneksi untuk Memfasilitasi Peningkatan Kemampuan Berpikir Kritis Mahasiswa

Suparni

Program Studi Pendidikan

Matematika. bahan ajar ini dibuat

dengan pendekatan integrasi

interkoneksi untuk memfasilitasi

peningkatan kemampuan berpikir

kritis mahasiswa. Pada langkah ini

terdiri dari beberapa tahap yaitu:

2) Membuat desain bahan ajar

Pembuatan desain ini diawali

dengan membuat draf yang berisi

bagian-bagian apa saja yang akan

dibahas dalam bahan ajar. bahan

ajar ini memuat cover, kata

pengantar, daftar isi, materi

hakikat matematika, dan daftar

pustaka.

3) Menyusun materi hakikat

matematika

Pada tahap ini, dijelaskan materi

hakikat matematika ada 6, dan

masing-masing

hakikat

diintegrasikan

dan

diinterkoneksikan dengan materi

keislaman dan bidang lain yang

terkait.

4) Pembuatan bahan ajar secara menyeluruh

Bahan ajar yang dikembangkan berukuran A5 yaitu $14,8 \mathrm{~cm}$ x 21

$\mathrm{cm}$ dibuat dengan menggunakan program MSWord.

Setelah dilakukan

pembuatan bahan ajar, selanjutnya

dilakukan proses editing dan bahan ajar ini mengalami beberapa

kali revisi berdasarkan kritik dan

saran dari reviewer hingga

dinyatakan layak oleh reviewer.

Bahan ajar selanjutnya dinilai oleh

penilai yaitu 5 mahasiswa yang

sudah menempuh mata kuliah

Strategi pembelajaran matematika,

dan 2 dosen ahli. penilaian bahan

ajar menggunakan lembar

instrumen penilaian kualitas bahan

ajar yang sebelumnya sudah

divalidasi oleh ahli. Penilaian

bahan ajar tersebut meliputi

beberapa aspek, yakni kebenaran

konsep, kedalaman konsep,

keluasan konsep, keterlaksanaan,

kebahasaan, anatomi bahan ajar,

dan tampilan menyeluruh.

5) Pembuatan Instrumen Penilaian

Bahan Ajar

Setelah membuat bahan

ajar, peneliti membuat instrumen

penilaian bahan ajar. Instrumen

Penilaian bahan ajar tersebut

merupakan instrumen yang

digunakan untuk menilai kualitas

bahan ajar berbasis integrasi

interkoneksi. Instrumen penilaian

bahan ajar tersebut terdiri dari

berbagai aspek yakni kebenaran

konsep, kedalaman konsep,

keluasan konsep, keterlaksanaan, 
kebahasaan, anatomi bahan ajar, dan tampilan menyeluruh.

Instrumen penilaian ini divalidasi oleh validatoe yang merupakan seorang ahli. Bahan ajar berbasis integrasi interkoneksi ini dinyatakan layak untuk digunakan apabila kualitas bahan ajar mendapat nilai minimal baik oleh penilai.

\section{Uji coba produk}

Langkah selanjutnya dalam pengembangan bahan ajar adalah uji coba produk. Instrumen penilaian bahan ajar divalidasi terlebih dahulu oleh validator, yaitu dua dosen pendidikan. Selanjutnya, instrumen tersebut digunakan untuk menilai kualitas bahan ajar. Penilai yang dimaksud adalah dua dosen sebagai ahli media.

Setelah dilakukan penilaian oleh para ahli, hasil penilaian dikonversi menjadi data tentang aspek kualitas bahan ajar yang dikembangkan kemudian saran, kritik dan komentar dari para ahli digunakan untuk revisi

Hasil penilaian dari materi dan ahli media adalah sebagai berikut.
Tabel 2. Hasil Penilaian Produk oleh Ahli Materi

\begin{tabular}{|c|c|c|c|c|}
\hline Aspek & $\begin{array}{l}\text { Rata } \\
\text {-rata } \\
\text { skor }\end{array}$ & $\begin{array}{l}\text { Skor } \\
\text { Mak- } \\
\text { simal }\end{array}$ & $\begin{array}{c}\text { Present } \\
\text { ase } \\
\text { keideal } \\
\text { an }\end{array}$ & $\begin{array}{l}\text { Kate } \\
\text { gori }\end{array}$ \\
\hline Kebenaran konsep & 13,5 & 15 & $90 \%$ & $\begin{array}{l}\text { Sangat } \\
\text { Baik }\end{array}$ \\
\hline Kedalaman konsep & 8,5 & 10 & $85 \%$ & $\begin{array}{l}\text { Sangat } \\
\text { Baik }\end{array}$ \\
\hline Keluasan konsep & 8,5 & 10 & $85 \%$ & $\begin{array}{l}\text { Sangat } \\
\text { Baik }\end{array}$ \\
\hline Keterlaksanaan & 13 & 15 & $87 \%$ & $\begin{array}{l}\text { Sangat } \\
\text { Baik }\end{array}$ \\
\hline Kebahasaan & 36,5 & 40 & $91 \%$ & $\begin{array}{l}\text { Sangat } \\
\text { Baik }\end{array}$ \\
\hline \multicolumn{3}{|c|}{ Rata-rata } & $87,6 \%$ & $\begin{array}{l}\text { Sangat } \\
\text { Baik }\end{array}$ \\
\hline
\end{tabular}

Tabel 3. Hasil Penilaian Produk oleh Ahli Media

\begin{tabular}{|c|c|c|c|c|}
\hline Aspek & $\begin{array}{c}\text { Rata- } \\
\text { rata } \\
\text { skor }\end{array}$ & $\begin{array}{c}\text { Skor } \\
\text { Maks } \\
\text { imal }\end{array}$ & $\begin{array}{c}\text { Prese } \\
\text { ntase } \\
\text { keide } \\
\text { alan }\end{array}$ & $\begin{array}{c}\text { Kate } \\
\text { gori }\end{array}$ \\
\hline Anatomi Bahan Ajar & 13 & 15 & $87 \%$ & $\begin{array}{c}\text { Sangat } \\
\text { Baik }\end{array}$ \\
\hline Mutu Bahan Ajar & 13 & 15 & $87 \%$ & $\begin{array}{c}\text { Sangat } \\
\text { Baik }\end{array}$ \\
\hline Tampilan menyeluruh & 21 & 25 & $84 \%$ & $\begin{array}{c}\text { Sangat } \\
\text { Baik }\end{array}$ \\
\hline \multicolumn{2}{|c|}{ Rata-rata } & $\mathbf{8 6 \%}$ & $\begin{array}{c}\text { Sangat } \\
\text { Baik }\end{array}$ \\
\hline
\end{tabular}

Tabel 4.Data Peningkatan Skor Tes Kemampuan Berpikir Kritis

\begin{tabular}{|l|l|c|c|c|}
\hline NO & \multicolumn{1}{|c|}{ HASIL } & $\begin{array}{c}\text { SKOR } \\
\text { PRETES }\end{array}$ & $\begin{array}{c}\text { SKOR } \\
\text { POSTES }\end{array}$ & $\begin{array}{c}\text { PENING } \\
\text { KATAN }\end{array}$ \\
\hline 1 & $\begin{array}{l}\text { Skor } \\
\text { terendah }\end{array}$ & 16 & 38 & 22 \\
\hline 2 & Skor tertinggi & 34 & 47 & 13 \\
\hline 3 & Rata-rata & 25,3513 & 42,8649 & 17,5135 \\
\hline
\end{tabular}

Peningkatan dari masing masing indikator kemampuan berpikir kritis mahasiswa kelas uji coba dapat digambarkan dengan diagram sebagai berikut.

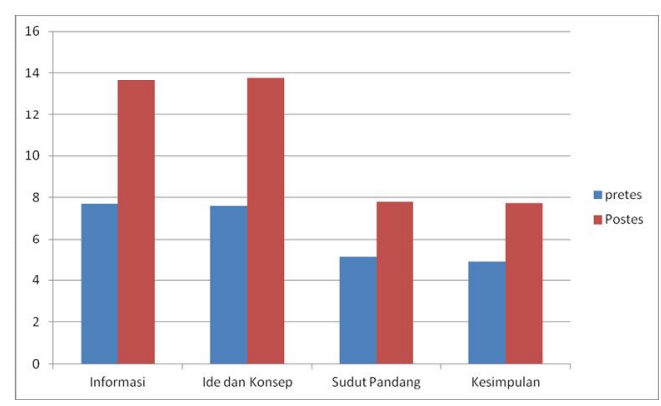

Gambar 1. Peningkatan Kemampuan Berpikir Kritis Mahasiswa 
Berdasarkan deskripsi hasil penelitian yang diuraikan sebelumnya, peneliti berhasil mengembangan bahan ajar berbasis integrasi interkoneksi berdasarkan model Research and Development yang diadaptasi dari model penelitian pengembangan Borg and Gall melalui 3 tahapan, yaitu tahap pendahuluan, pengembangan, dan uji coba.

Pada tahap pendahuluan
dilakukan pengamatan terhadap
pembelajaran di kelas melalui observasi
dan wawancara dengan mahasiswa
mengenai pembelajaran matematika
khususnya pada mata kuliah Strategi
Pembelajaran matematika dan
permasalahan yang terjadi, analisis
kurikulum mengenai tujuan

perkuliahan, melakukan studi pustaka untuk menentukan solusi yang sekiranya tepat untuk memenuhi kebutuhan perkuliahan yang berkaitan dengan kemampuan berpikir kritis mahasiswa yang rendah, observasi dan wawancara terhadap mahasiswa untuk mengetahui respon dari penggunaan media pembelajaran yang telah dipakai selama ini.

Dari pengamatan terhadap pembelajaran matematika ditemukan permasalahan bahwa kemampuan berpikir kritis mahasiswa masih rendah. Hasil analisis kurikulum menunjukkan bahwa pada materi hakikat matematika memang diperlukan media pembelajaran yang edukatif yang dapat membantu mahasiswa dalam meningkatkan kemampuan berpikir kritis mahasiswa. Dari hasil studi pustaka ditemukan bahwa salah satu alternatif yang dapat digunakan untuk memenuhi kebutuhan belajar yang berhubungan dengan kemampuan berpikir kritis mahasiswa adalah penggunaan bahan ajar berbasis integrasi interkoneksi.

Pada tahap pengembangan dilakukan pembuatan bahan ajar berbasis interkoneksi dengan memperhatikan indikator-indikator kemampuan berpikir kritis mahasiswa yang digunakan dalam penelitian ini, penyusunan instrumen dengan validasi ahli, penilaian bahan ajar oleh ahli, revisi I, uji coba terbatas kelompok kecil, dan uji coba terbatas kelompok besar.

\section{KESIMPULAN}

Bahan ajar berbasis integrasi interkoneksi dengan kualitas sangat baik dengan persentase keidealan sebesar 87,6 $\%$ dari ahli materi, $86 \%$ ahli media, dan mampu meningkatkan kemampuan berpikir kritis mahasiswa sebesar 17,5135 


\section{REFERENSI}

Elder, L Paul, R. 2008. Critical Thinking Development: A Stage Theory With Implicationn for Instruction, (Online), (http://www.criticalthinking.org)

Facione, P.A. 2009. Critical Thinking: What It is and Why It Counts. Insight Assessment, (Online) (http://www.insightassessment.co m)

Halpern, Diane F. 1984. Thought and Knowledge. An Introduction to Critical Thinking. LEA. New Jersey.

Ibrahim dan Suparni. 2010. Pembelajaran Matematika. Teori dan Aplikasinya. Sukapress. Yogyakarta

McGregor, Debra. 2007. Developing Thinking; Developing Learning. McGrawHill. New Jersey.

Seng Tan, Oon. 2004. Enhancing Thinking Through Problem based Learning Approaches. Thomson. Singapura.

Sugiyono. 2008. Metode Penelitian Pendidikan Pendekatan Kuantitatif, Kualitatif, dan $R \& D$. Bandung: Alfabeta.

2006. Kerangka Dasar Keilmuan dan Pengembangan Kurikulum UIN Sunan Kalijaga. Pokja Akademik. UIN Sunan Kalijaga. Yogyakarta

Suparni. 2011. Penjenjangan Kemampuan Berpikir Kritis Dalam Rangka Pengembangan Karakter Mahasiswa Program Studi Pendidikan Matematika Fakultas Sains dan Teknologi UIN
Sunan Kalijaga. UIN Sunan Kalijaga. Yogyakarta. . 2013. Pengembangan

Kemampuan Berpikir Kritis Mahasiswa Program Studi Pendidikan Matematika Melalui Pendekatan Integrasi Interkoneksi. UIN Sunan Kalijaga. Yogyakarta.

\section{Kemampuan Berpikir Kritis Mahasiswa Program Studi Pendidikan Matematika Melalui Pendekatan Integrasi Interkoneksi. UIN Sunan Kalijaga. Yogyakarta}

